\title{
CURAHAN WAKTU KERJA WANITA DALAM KELUARGA PETANI WORTEL DI KELURAHAN RURUKAN KECAMATAN TOMOHON TIMUR KOTA TOMOHON
}

\author{
Remin Dina Maradou \\ Martha Mereyke Sendow \\ Welson Marthen Wangke
}

\begin{tabular}{ll}
\hline Naskah diterima melalui Website Jurnal Ilmiah agrisosioekonomi@unsrat.ac.id & : Jumat, 12 Juli 2019 \\
Disetujui diterbitkan & : Rabu, 24 Juli 2019 \\
\hline
\end{tabular}

\begin{abstract}
The purpose of this study was to determine the outpouring of women's working time in the family of carrot farmers, in the form of activities in the family and outside the family for carrot farming. This research was conducted for four months from October 2018 to January 2019. The data used in this study were primary data and secondary data. Primary data is obtained through direct interviews based on a list of questions to all female carrot farmers, in research location, as many as 17 people both as land owners and as land borrowers who seek carrot farming and have a family. Secondary data was obtained from the Rurukan Village Office and the internet through the Google Scholar to obtain articles, journals, and thesis related to the topic of research on the outpouring of women's working time in the farmer's family. The analysis used is descriptive analysis and in table form. The results of the study showed that the total work time of women in the carrot farmer family in Rurukan Village, Tomohon Timur SubDistrict in the largest one week in the type of work in the family by all respondents was 251 hours and an average of 14.76 per respondent, compared to outpouring time outside the family for carrot farming in one week by all respondents was 56.16 hours and an average of 3.30 per respondent. ${ }^{* e p r m *}$
\end{abstract}

Keywords: allocation time of working for women, carrot farmer families, Rurukan Village, Tomohon City

\begin{abstract}
ABSTRAK
Tujuan penelitian ini adalah untuk mengetahui curahan waktu kerja wanita dalam keluarga petani wortel, berupa kegiatan dalam keluarga dan di luar keluarga untuk usahatani wortel. Penelitian ini dilaksanakan selama empat bulan dari bulan Oktober 2018 sampai dengan Januari 2019. Data yang digunakan dalam penelitian ini adalah data primer dan data sekunder. Data primer diperoleh melalui wawancara lansung berdasarkan daftar pertanyaan kepada semua petani wortel perempuan, di lokasi penelitian, sebanyak 17 orang baik sebagai pemilik lahan maupun sebagai peminjam lahan yang mengusahakan usahatani wortel dan telah berkeluarga. Data sekunder diperoleh dari Kantor Kelurahan Rurukan dan internet melalui google scholar untuk mendapatkan artikel, jurnal, dan skripsi yang berkaitan dengan topik penelitian tentang curahan waktu kerja wanita dalam keluarga petani. Analisis yang digunakan adalah analisis deskriptif dan dalam bentuk tabel. Hasil penelitian yang dilakukan menunjukkan bahwa total curahan waktu kerja wanita dalam keluarga petani wortel di Kelurahan Rurukan Kecamatan Tomohon Timur dalam satu minggu terbesar pada jenis pekerjaan di dalam keluarga oleh semua responden sebesar 251 jam dan rata-rata 14,76 per responden, dibandingkan dengan curahan waktu di luar keluarga untuk usahatani wortel dalam satu minggu oleh semua responden sebesar 56,16 jam dan rata-rata 3,30 per responden. ${ }^{* e p r m *}$
\end{abstract}

Kata kunci: curahan waktu kerja wanita, keluarga petani wortel, Kelurahan Rurukan, Kota Tomohon 


\section{PENDAHULUAN}

\section{Latar Belakang}

Sektor pertanian masih menjadi sumber mata pencaharian utama bagi masyarakat Indonesia. Menteri Pertanian mengungkapkan bahwa sektor pertanian adalah penyerap tenaga kerja terbesar di Indonesia yang juga melibatkan tenaga kerja perempuan. Tahun 2010 diperhitungkan sekitar 0,8 juta tenaga kerja yang mampu diserap dari berbagai sektor pertanian. Penyerapan tenaga kerja disektor pertanian masih tetap tinggi yaitu sekitar 41 juta orang atau separuh dari angkatan kerja nasional (Faisal dalam Widyarini, 2013). Partisipasi kaum wanita dalam berbagai kegiatan ekonomi telah meningkat secara berarti pada semua sektor, terutama di kalangan wanita pekerja muda dan di sektor moderen. Tidak saja pada keseluruhan pasar kerja tetapi terlebih di sektor formal telah terjadi proses feminisasi dan status wanita pekerja telah membaik. Perkembangan demikian terjadi pada periode pertumbuahan ekonomi dan perubahan struktural yang cepat, pasar kerja umumnya telah membaik (Zannatos, 2004).

Fenomena wanita bekerja di sektor pertanian bagi masyarakat bukan sesuatu hal yang baru. Sejarah menunjukkan bahwa asal mula pertanian berawal dari pembagian kerja antara pria dan wanita, dimana pria melakukan pekerjaan berburu dan meramu hasil hutan, sedangkan wanita bertani di sekitar rumah dan mengerjakan pekerjaan rumah tangga. Semakin maju masyarakat maka usaha pertanian dilakukan secara menetap dan dilakukan oleh pria dan wanita. Masuknya tenaga kerja wanita ke sektor pertanian didorong oleh kebutuhan pokok masyarakat (Sukesi dalam Sofwan, 2016). Menurut Putri et al (2007) curahan waktu kerja wanita secara garis besar dibagi menjadi dua yaitu: curahan waktu kerja untuk kegiatan ekonomi (mencari nafkah) dan kegiatan non ekonomi yaitu kegiatan dasar, kegiatan sosial, dan kegiatan rumah tangga. Secara umum wanita mempunyai peran baik sebagai ibu rumah tangga maupun sebagai pencari nafkah, dilakukan dalam kehidupan sehari-hari yang tercermin dalam curahan waktu kerja wanita.

Dalam dunia pertanian, wanita tidak hanya berperan sebagai ibu rumah tangga saja, namun banyak ditemui pula wanita yang berperan atau secara langsung memberi kontribusi nyata terhadap usahatani yang diusahakan oleh keluarga itu sendiri. Kegiatan usahatani yang dilakukan oleh wanita tani dipengaruhi oleh curahan waktu kerja.
Curahan waktu kerja wanita dalam kegiatan yang produktif banyak tergantung pada faktor sosial ekonomi dan keadaan keluarganya. Faktor-faktor sosial ekonomi yang berpengaruh pada curahan waktu kerja wanita tani adalah tingkat umur, jumlah tanggungan keluarga, tingkat upah, luas lahan, status perkawinan, tingkat pendidikan dan tingkat pengalaman (Novita, 2012).

Kelurahan Rurukan merupakan salah satu kelurahan yang berada di kecamatan Tomohon Timur, Kota Tomohon dengan luas wilayah Kelurahan Rurukan adalah sekitar $350 \mathrm{Ha}$, dengan luas lahan pertanian $\pm 292 \mathrm{Ha}$ dan jumlah penduduk 1809 jiwa sebagian besar penduduknya bermatapencaharian sebagai petani hortikultura. Dari total jumlah penduduk di Kelurahan Rurukan terdapat 268 petani wanita. Kawasan Rurukan merupakan daerah sentra produksi hortikultura yaitu sayuran, buah-buahan seperti wortel, labu siam, buncis, bawang daun, kubis petsai bunga kol, dan stroberi. Dalam penelitian ini yang menjadi objek penelitian adalah wanita yang berkeluarga dan bekerja pada usahatani wortel di Kelurahan Rurukan Kecamatan Tomohon Timur.

\section{Rumusan Masalah}

Berdasarkan latar belakang maka perumusan masalah adalah berapa besar curahan waktu kerja wanita dalam Keluarga dan luar keluarga (usahatani) wortel di Kelurahan Rurukan Kecamatan Tomohon Timur.

\section{Tujuan Penelitian}

Berdasarkan perumusan masalah, maka yang menjadi tujuan penelitian adalah untuk mengetahui besarnya curahan waktu kerja wanita dalam kegiatan domestik (Keluarga) dan kegiatan usahatani wortel di Kelurahan Rurukan Kecamatan Tomohon Timur.

\section{Manfaat Penelitian}

1. Manfaat dari penelitian ini yaitu sebagai bahan informasi bagi pemerintah dalam menentukan kebijaksanaan pembangunan khususnya dalam peningkatan peran wanita dalam pengembangan usahatani wortel.

2. Penelitian ini juga diharapkan dapat menjadi bahan studi referensi untuk penelitian selanjutnya dan referensi dalam melaksanakan penelitian serupa. 


\section{METODE PENELITIAN}

\section{Tempat dan Waktu Penelitian}

Penelitian ini dilaksanakan selama 4 bulan yaitu dari bulan oktober sampai bulan januari 2019. Mulai dari persiapan sampai penyusunan laporan penelitian. Tempat penelitian di Kelurahan Rurukan Kecamatan Tomohon Timur Kota Tomohon.

\section{Metode Penelitian}

Metode yang digunakan dalam penelitian ini yaitu deskriptif kualitatif dengan memilih sampel survey di Kelurahan Rurukan.

\section{Metode Pengumpulan Data}

Penelitian ini menggunakan data primer dan data sekunder. Data primer diperoleh melalui wawancara langsung pada wanita tani yang berkeluarga dan bekerja pada usahatani wortel dari kegiatan pembibitan, pengolahan tanah, penanaman, penyiangan, pengendalian hama dan penyakit, pemupukan dan panen, dengan menggunakan daftar pertanyaan yang telah di siapkan berupa kuesioner, data sekunder diperoleh dari kantor Kelurahan Rurukan serta instansi yang terkait dalam penelitian ini.

\section{Metode Pengambilan Sampel}

Populasi dalam penelitian ini yaitu semua wanita yang sudah berkeluarga dan bekerja pada usaha tani wortel, diambil semua wanita yang berkeluarga dan bekerja dalam usahatani wortel yaitu ada 17 responden.

\section{Konsep Pengukuran Variabel}

Batasan varibel yang akan diteliti adalah

1. Umur Responden (tahun)

2. Pendidikan Responden (SD, SLTP, SLTA, PT)

3. Jumlah Tanggungan Keluarga (Jiwa)

4. Luas Lahan (Ha)

5. Curahan waktu kerja dalam keluarga yaitu :
a. Membersihkan rumah Jam/hari
b. Mengasuh Anak Jam/hari
c. Mencuci Pakaian Jam/hari
d. Memasak Jam/hari
e. Membersihkan halaman rumah Jam/hari

6. Curahan waktu kerja diluar keluarga (Usahatani wortel) yaitu:

a. Pembibitan Jam/hari

b. Pengolahan tanah Jam/hari

c. Penanaman Jam/hari

d. Penyiangan Jam/hari

e. Pengendalian Hama dan Penyakit Jam/hari

f. Pemupukan Jam/hari

g. Panen Jam/hari

\section{Metode Analisis Data}

Metode analisis data yang digunakan dalam penelitian ini adalah analisis deskriptif, dimana data yang terkumpul disajikan dalam bentuk tabel.

\section{HASIL DAN PEMBAHASAN}

\section{Deskripsi Lokasi Penelitian}

Kelurahan Rurukan terletak di Kecamatan Tomohon Timur Kota Tomohon Provinsi Sulawesi Utara dan berada pada ketinggian 1100-1300 dpl dengan luas wilayah $\pm 350 \mathrm{Ha}$. Kelurahan Rurukan terdiri dari 463 KK dengan jumlah penduduk 1.808 jiwa yang terdiri dari 954 laki-laki dan 854 perempuan yang sebagian besar penduduk kelurahan Rurukan bermata pencaharian sebagai petani.

\section{Keadaan Geografis Lokasi Penelitian}

Kelurahan Rurukan merupakan salah satu dari 5 kelurahan di Kecamatan Tomohon Timur Kota Tomohon yang memiliki luas lahan \pm 350 Ha. Secara administrative Kelurahan Rurukan berbatasan dengan :

Sebelah Utara : Kelurahan Kumelembuai

Sebelah Selata : Kabupaten Minahasa

Sebelah Timur : Rurukan Satu

Sebelah Barat : Talete Satu dan Paslaten Satu

\section{Keadaan Penduduk}

Berdasarkan data demografi Kelurahan Rurukan, menunjukkan bahwa jumlah penduduk Kelurahan Rurukan adalah 1.808 Jiwa. Jumlah ini terdiri dari penduduk laki-laki yang sebanyak 954 jiwa dan penduduk perempuan sebanyak 854 jiwa. Jumlah penduduk menurut jenis kelamin dapat dilihat pada Tabel 1. 
Tabel 1. Jumlah Penduduk Menurut Jenis Kelamin

\begin{tabular}{clcr}
\hline No & Jenis Kelamin & Jumlah & Persentase (\%) \\
\hline 1 & Laki-Laki & 954 & 52,77 \\
2 & Perempuan & 854 & 47,23 \\
\hline \multicolumn{2}{l}{ Total } & 1.808 & 100 \\
\hline \multicolumn{2}{l}{ Sumber: Data Profil Kelurahan Rurukan }
\end{tabular}

Sumber: Data Profil Kelurahan Rurukan, tahun 2018

\section{Mata Pencaharian}

Penduduk Kelurahan Rurukan bermata pencaharian utama sebagai petani, buruh tani, wiraswasta, PNS, dan ada juga pensiunan. Jumlah Penduduk menurut mata pencaharian dapat dilihat pada Tabel 2.

Tabel 2. Jumlah Penduduk Menurut Mata Pencaharian

\begin{tabular}{llcr}
\hline No. & $\begin{array}{c}\text { Mata } \\
\text { Pencaharian }\end{array}$ & Jumlah (Orang) & Persentase (\%) \\
\hline 1. & Petani & 760 & 72,24 \\
2. & Buruh Tani & 130 & 12,35 \\
3. & PNS & 45 & 4,28 \\
4. & Pensiunan & 29 & 2,76 \\
5. & Wiraswasta & 39 & 3,71 \\
6. & Swasta & 49 & 4,66 \\
\hline & Total & 1.052 & 100 \\
\hline
\end{tabular}

Sumber: Data Profil Kelurahan Rurukan tahun 2018

Dari Tabel 2 dapat dilihat bahwa sebagian besar penduduk Kelurahan Rurukan mempunyai sumber mata pencaharian utama sebagai petani $72,24 \%$ atau sebanyak 760 Jiwa, dan 130 jiwa atau 12,35\% yang bermata pencaharian sebagai buruh tani, 49 jiwa atau $4,66 \%$ yang berprofesi sebagai swasta, dan 45 jiwa atau $4,28 \%$ berprofesi sebagai PNS, 39 jiwa atau 3,71 berprofesi sebagai wiraswasta, dan presentase terkecil adalah pensiunan yaitu 29 jiwa atau $2,76 \%$.

\section{Karakteristik Responden}

\section{Umur Petani}

Umur sangat mempengaruhi kemampuan seseorang dalam bekerja atau peranannya dalam pengambilan keputusan dari berbagai alternatif pekerjaan yang dilakukan. Jika ditinjau dari segi fisik, semakin tua umur seseorang setelah melewati batas umur tertentu, maka semakin berkurang kemampuan untuk bekerja. Menurut penelitian yang sudah dilakukan umur responden dapat dilihat pada Tabel 3.
Tabel 3. Jumlah dan Persentase Petani Responden Menurut Kelompok Umur

\begin{tabular}{llcc}
\hline No. & Umur (Tahun) & Jumlah (Orang) & Persentase $(\%)$ \\
\hline 1. & $<30$ & 1 & 5,89 \\
2. & $30-45$ & 6 & 35,29 \\
3. & $46-55$ & 8 & 47,05 \\
4. & $>55$ & 2 & 11,76 \\
\hline & Total & 17 & 100 \\
\hline
\end{tabular}

Sumber: Data Profil Kelurahan Rurukan tahun 2018

Hasil penelitian menunjukkan bahwa $47,05 \%$ petani responden masih berada dalam kelompok umur produktif yaitu berkisar antara 30 - 50 tahun, dimana golongan ini termasuk golongan umur yang masih produktif dalam arti kondisi fisik dan kemampuan kerjanya baik.

\section{Tingkat Pendidikan Petani}

Tingkat pendidikan merupakan faktor yang sangat penting yang menentukan tingkat kecakapan petani dalam menjalankan tugas serta fungsinya dengan baik sebagai manejer maupun sebagai juru tani. Semakin tinggi tingkat pendidikan seorang petani maka semakin mudah menerima masukan dan saran dalam mengelola usahanya. Berdasarkan penelitian tingkat pendidikan responden dapat dilihat pada Tabel 4.

Tabel 4. Jumlah dan Persentase Petani Responden Menurut Tingkat Pendidikan

\begin{tabular}{llcr}
\multicolumn{4}{c}{ Tingkat Pendidikan } \\
No. & Tingkat & Jumlah (Orang) & Persentase (\%) \\
& Pendidikan & 3 & 17,65 \\
\hline 1. & SD & 9 & 52,94 \\
2. & SMP & 5 & 29,41 \\
3. & SMA & 17 & 100 \\
\hline & Total
\end{tabular}

Sumber : Data Primer November 2018

Tabel 4 menunjukkan bahwa tingkat pendidikan petani di Kelurahan Rurukan, memiliki tingkat pendidikan terbanyak yaitu $52,94 \%$ pada tingkat pendidikan SMP, sedangkan $29,41 \%$ berada pada tingkat pendidikan SMA, dan pada tingkat pendidikan Sekolah Dasar (SD) hanya mencapai 17,65\%.

\section{Jumlah Anggota keluarga}

Jumlah anggota keluarga adalah jumlah orang yang masih menjadi tanggungan dalam satu keluarga. Jumlah keluarga petani responden berkisar antara 3 orang sampai 7 orang. Keadaan jumlah anggota keluarga dapat dilihat pada Tabel 5. 
Tabel 5. Jumlah dan Persentase Petani Menurut Jumlah Tanggungan

\begin{tabular}{llcr}
\hline No. & $\begin{array}{l}\text { Jumlah } \\
\text { Tanggungan }\end{array}$ & Jumlah (Orang) & Persentase (\%) \\
\hline 1. & $3-4$ & 11 & 64,70 \\
2. & $5-6$ & 5 & 29,41 \\
3. & $7-8$ & 1 & 5,89 \\
\hline & Total & 17 & 100 \\
\hline
\end{tabular}

Sumber : Data Primer November 2018

Tabel 5 menunjukkan bahwa jumlah anggota keluarga atau tanggungan keluarga petani responden antara 3 - 4 orang yaitu 11 responden atau $64,70 \%$ dan diikuti pada jumlah tanggungan keluarga antara 5 - 6 orang yaitu 5 responden atau $29,41 \%$ sedangkan pada tanggungan 7 - 8 orang yaitu 1 responden atau $5,89 \%$.

\section{Luas Lahan}

Luas lahan merupakan faktor produksi penting dalam kegiatan usahatani. Keadaan lahan serta luas suatu lahan sangat berpengaruh pada tingkat produksi serta peran seorang wanita dalam usahatani yang diusahakan.

Tabel 6. Luas Lahan Responden

\begin{tabular}{clcr}
\hline No & Luas Lahan (Ha) & Jumlah & Persentase (\%) \\
\hline 1 & $>0,5$ & 10 & 58,83 \\
2 & $0,5-1,0$ & 7 & 41,17 \\
\hline \multicolumn{2}{l}{ Total } & 17 & 100 \\
\hline
\end{tabular}

Sumber : Data Primer, 2018

Tabel 6 menunjukkan bahwa sebagian besar responden memiliki luas lahan dengan kisaran $<0,5 \mathrm{Ha}$ yaitu mencapai 10 responden atau $58,83 \%$ sedangkan responden yang memiliki luas lahan antara $0,5-1,0 \mathrm{Ha}$ berjumlah 7 orang atau $41,17 \%$.

\section{Curahan Waktu Kerja Wanita Dalam Keluarga Petani Wortel di Kelurahan Rurukan}

Curahan kerja adalah jumlah waktu yang dialokasikan untuk melakukan serangkaian kegiatan yang biasa dilakukan didalam dan luar rumah tangga dalam satuan waktu atau jam. Putri et al (2007) curahan waktu kerja wanita secara garis besar dibagi menjadi dua, yaitu curahan waktu kerja untuk kegiatan ekonomi, yaitu kegiatan dasar, kegiatan sosial, dan kegiatan rumah tangga.
Dalam penelitian ini dilihat adalah kegiatan wanita didalam keluarga jam/minggu mulai membersihkan rumah, memasak, mencuci pakaian, mengasuh anak, dan diluar keluarga yaitu pada usahatani wortel yang dilakukan jam/minggu untuk beberapa jenis kegiatan mulai dari pembibitan, pengolahan tanah, penanaman, pengendalian hama dan penyakit, penyiangan, pemupukan, dan panen.

\section{Curahan Waktu pada Jenis Pekerjaan Dalam Keluarga}

Wanita dalam Keluarga petani wortel di Kelurahan Rurukan ikut berperan dalam usahatani (membantu suami) dalam proses usahatani wortel, selain itu dalam keluarga tidak lepas dari perannya mengurus pekerjaan rumah tangga, memasak, mencuci pakaian, mengasuh anak adalah tanggung jawab utama seorang istri.

Dalam penelitian ini wanita melakukan kegiatan dalam keluarga mulai dari bangun pagi pukul 05.00-18.00 WITA. Pada pukul 05.30 wanita mulai merebus air, menyiapkan sarapan, kemudian mengurus pekerjaan rumah tangga seperti memasak, membersihkan rumah, mengurus anak, pukul 08.30 WITA. Pada Pukul 09.00-16.00 WITA wanita tani bekerja di kebun, dan setelah pulang dari kebun pukul 17.30-18.00 Wita wanita memasak atau mempersiapkan makanan untuk makan malam.

\begin{tabular}{llccr} 
Tabel 7. Curahan Waktu Rata-rata dan Persentase & Kerja \\
\multicolumn{5}{c}{ Wanita Pada Jenis Pekerjaan dalam Keluarga } \\
\hline No. & $\begin{array}{c}\text { Jenis } \\
\text { Kegiatan }\end{array}$ & $\begin{array}{c}\text { Jumlah } \\
\text { Jam/ } \\
\text { Minggu }\end{array}$ & $\begin{array}{c}\text { Rata-rata } \\
\text { Jam } \\
\text { /Responden }\end{array}$ & Persentase (\%) \\
& & 42 & 2,47 & 16,74 \\
\hline 1. & M Rumah & 122 & 7,17 & 48,60 \\
2. & Memasak & 14 & 0,83 & 5,58 \\
3. & Mengasuh anak & 61 & 3,58 & 24,30 \\
4. & Mencuci pakaian & 12 & 0,71 & 4,78 \\
5. M halaman Rumah & 12 & 251 & 14,76 & 100 \\
\hline \multicolumn{4}{l}{ Total } &
\end{tabular}

Sumber: Data Profil Kelurahan Rurukan tahun 2018

Hasil penelitian pada Tabel 7 menunjukkan bahwa curahan waktu rata-rata wanita dalam keluarga adalah 14,76 jam perminggu pada jenis pekerjaan dalam keluarga mulai dari membersihkan rumah, memasak, mengasuh anak, mencuci pakaian, membersihkan halaman. 


\section{Membersihkan Rumah}

Pekerjaan membersihkan rumah yang dilakukan adalah menyapu, merapikan perabotan rumah. Dalam penelitian ini yang dilihat bagaimana curahan waktu kerja wanita dalam jenis pekerjaan membersihkan rumah. Tabel 7 menunjukkan jumlah dan persentase pada jenis pekerjaan membersihkan rumah.

Hasil penelitian menunjukkan bahwa pada jenis pekerjaan membersihkan rumah jam perminggu, jumlah jam yang dicurahkan sebesar 42 jam dengan persentase $16,74 \%$ dan rata-rata 2,47 jam per responden pada jenis pekerjaan membersihkan rumah.

\section{Memasak}

Pekerjaan memasak yang dilakukan mulai dari menyiapkan bahan-bahan makanan, memilih dan membersihkan rempah-rempah, kemudian bahan-bahan diolah agar dapat dikomsumsi, seperti memasak nasi, dan lauk pauk. kemudian setelah memasak ataupun sementara memasak sekaligus mencuci piring, dan peralatan masak yang telah selesai digunakan.

Hasil penelitian menunjukkan bahwa pada jenis pekerjaan memasak jam per minggu, jumlah jam yang dicurahkan sebesar 122 jam dengan persentase $48,60 \%$ dan rata-rata 7,17 jam per responden pada jenis pekerjaan memasak.

\section{Mengasuh Anak}

Pekerjaan mengasuh anak yang dilakukan adalah menyiapkan seragam untuk dipakai ke sekolah, memberi makan, dan membantu mengerjakan tugas dari sekolah,. Dari 17 responden dalam penelitian ini ada dua responden yang melakukan pekerjaan mengasuh anak.

Hasil penelitian menunjukkan bahwa pada jenis pekerjaan mengasuh anak jam per minggu, jumlah jam yang dicurahkan sebesar 14 jam dengan persentase $5,58 \%$ dan rata-rata 0,83 jam per responden pada jenis pekerjaan mengasuh anak.

\section{Mencuci Pakaian}

Pekerjaan mencuci pakaian yang dilakukan adalah menampung air, merendam baju yang akan dicuci dengan sabun, lalu disikat, kemudian dibilas dan dijemur.
Hasil penelitian menunjukkan bahwa pada jenis pekerjaan mencuci pakaian jam per minggu, jumlah jam yang dicurahkan sebesar 61 jam dengan persentase $24,30 \%$ dan ratarata 3,58 jam per responden pada jenis pekerjaan mengasuh anak.

Dalam penelitian ini pada jenis pekerjaan mencuci pakaian yang dimaksud rata-rata jam per responden tidak termasuk pada hari minggu.

\section{Membersihkan Halaman Rumah}

Pekerjaan membersihkan halaman rumah yang dilakukan adalah menyapu dan mencabut rumput yang tumbuh dihalaman rumah. Dari 17 responden dalam penelitian ini yang melakukan pekerjaan membersihkan halaman rumah ada 13 responden dan pada responden lain ada anak yang membantu menyapu halaman rumah.

Hasil penelitian menunjukkan bahwa pada jenis pekerjaan membersihkan halaman rumah jam per minggu, jumlah jam yang dicurahkan sebesar 12 jam dengan persentase $4,78 \%$ dan rata-rata 0,71 jam per responden pada jenis pekerjaan membersihkan halaman rumah. Dalam penelitian ini pada jenis pekerjaan membersihkan halaman rumah yang dimaksud rata-rata jam per responden tidak termasuk pada hari minggu.

\section{Curahan Waktu Kerja Wanita pada Jenis Pekerjaan di Luar Keluarga (usahatani wortel)} Wanita dalam keluarga petani wortel di Kelurahan Rurukan pada umumnya tidak lepas dari perannya mengurus rumah tangga namun ikut juga bekerja dalam usahatani wortel untuk membantu suami. Tenaga kerja merupakan salah satu factor paling utama dalam keberhasilan suatu usahatani baik itu Tenaga kerja laki-laki maupun tenaga kerja wanita.

Dalam penelitian ini dilihat adalah curahan waktu kerja wanita di luar keluaraga (Usahatani wortel) jam per minggu untuk beberapa jenis kegiatan mulai dari pembibitan, pengolahan tanah, penanaman, pengendalian hama dan penyakit, penyiangan, pemupukan dan panen, dengan jam kerja dimulai pukul $09.00-16.00$ WITA. 
Tabel 8. Curahan Waktu Rata-Rata dan Persentase Kerja Wanita Pada Jenis Pekerjaan diLuar Keluarga (Usahatani Wortel)

\begin{tabular}{llcrr}
\hline No. & \multicolumn{1}{c}{$\begin{array}{c}\text { Jenis } \\
\text { Pekerjaan }\end{array}$} & $\begin{array}{c}\text { Jumlah } \\
\text { Jam/ } \\
\text { Minggu }\end{array}$ & $\begin{array}{c}\text { Rata-rata } \\
\text { Jam } \\
\text { /Responden }\end{array}$ & Persentase (\%) \\
\hline 1. Pembibitan & 11 & 2,47 & 16,74 \\
2. $\begin{array}{l}\text { Pengolahan } \\
\text { Tanah }\end{array}$ & 3,58 & 7,17 & 48,60 \\
3. Penanaman & 9,75 & 0,83 & 5,58 \\
4. Penyiangan & $28,751,69$ & 3,58 & 24,30 \\
5. Pemupukan & $3,080,18$ & 0,71 & 4,78 \\
6. Pengendalian & 0 & 0 & 0,00 \\
& Hama & & & \\
Penyakit & 0 & 0 & 0,00 \\
7. Panen & 56,16 & 3,30 & 100 \\
\hline & Total \\
\hline Sumber data : diolah dari data primer, 2018
\end{tabular}

Hasil penelitian menunjukkan bahwa pada jenis pekerjaan diluar keluarga (Usahatani wortel) di Kelurahan Rurukan mulai dari kegiatan pembibitan, pengolahan tanah, penanaman, penyiangan, pemupukan, pengendalian hama dan penyakit dan panen hanya pada kegiatan pengendalian hama dan penyakit dan juga pada kegiatan panen wanita tidak berperan. Pada kegiatan pengendalian hama dan penyakit hanya dilakukan oleh lakilaki, sedangkan pada kegiatan pemanenan pembeli yang datang langsung untuk memanen wortel.

\section{Kegiatan Pembibitan}

Kegiatan pembibitan yang dilakukan adalah mencabut tanaman wortel yang akan dijadikan bibit dan akan ditanam kembali, dengan memilih umbi wortel yang baik, dan pemeliharaan keseluruhan dalam pembibitan. Dalam penelitian ini dilihat bagaimana tenaga kerja wanita dalam kegiatan pembibitan serta jam kerja yang dicurahkan saat kegiatan pembibitan.

Dari 17 responden dalam penelitian ini yang melakukan kegiatan pembibitan ada 15 responden dan 2 responden lain tidak melakukan kegiatan pembibitan karena kegiatan pembibitan dilakukan oleh laki-laki.

Hasil penelitian menunjukkan bahwa pada kegiatan pembibitan jam per minggu, jumlah jam yang dicurahkan sebesar 11 jam dengan persentase sebesar $19,60 \%$ dan rata-rata sebesar 0,64 jam per responden pada kegiatan pembibitan wortel.

\section{Kegiatan Pengolahan Tanah}

Kegiatan yang dilakukkan dalam pengolahan tanah adalah mencangkul dan pembuatan bedengan-bedengan. Dalam penelitian ini dilihat bagaimana peran tenaga kerja wanita dalam kegiatan pengolahan tanah serta jam kerja yang dicurahkan dalam kegiatan tersebut. 17 responden dalam penelitian ini yang melakukkan kegiatan pengolahan tanah ada 3 responden dan 14 responden tidak melakukan kegiatan pengolahan tanah karena kegiatan pengolahan tanah dilakukan oleh laki-laki, Tabel 8 menunjukan jumlah dan persentase dalam kegiatan pengolahan tanah.

Hasil penelitian menunjukkan bahwa pada kegiatan pengolahan tanah jam per minggu, wanita berperan dalam kegiatan pengolahan tanah dengan jumlah jam yang dicurahkan sebesar 3,58 jam dengan persentase $6,37 \%$ dan rata-rata jam per responden sebesar 0,21 jam pada kegiatan pengolahan tanah.

\section{Kegiatan Penanaman}

Kegiatan yang dilakukan dalam penanaman adalah membuat garis pada bedengan lalu menanam bibit yang telah disediakan. Dalam penelitian ini bertujuan untuk melihat peran wanita dalam kegiatan penanaman yang dilihat dari jumlah waktu yang dicurahkan dalam kegiatan penanaman. Tabel 8 menunjukkan jumlah dan persentase dalam kegiatan penanaman.

Hasil penelitian pada kegiatan penanaman jam per minggu, wanita berperan dalam kegiatan penanaman dengan jumlah jam yang dicurahkan sebesar 9,75 jam dengan persentase $17,35 \%$ dan rata-rata 0,57 jam per responden pada kegiatan penanaman wortel.

\section{Kegiatan Penyiangan}

Dalam kegiatan penyiangan usahatani wortel, kegiatan ini dilakukan dua kali dalam satu priode tanam, pekerjaan yang dilakukkan adalah mencabut rumput atau tanaman liar yang tumbuh di sekitar tanaman serta penjarangan tanaman. Dalam penelitian ini bertujuan untuk melihat peran wanita dalam kegiatan penyiangan serta berapa besar jam kerja yang dicurahkan jam per minggu. Tabel 8 menunjukkan jumlah dan persentase pada kegiatan penyiangan. 
Hasil penelitian menunjukkan bahwa pada kegiatan penyiangan jam per minggu, wanita berperan dalam kegiatan penyiangan dengan jumlah jam yang dicurahkan sebesar 28,75 jam dengan persentase sebesar $51,18 \%$ dan rata-rata sebesar 1,69 jam per responden pada kegiatan penyiangan.

\section{Kegiatan Pemupukan}

Kegiatan yang dilakukan dalam pemupukan adalah pemberian pupuk pada tanah yang telah diolah. Dalam penelitian ini ingin dilihat bagaimana peran tenaga kerja wanita dalam kegiatan pemupukan dalam satu periode tanam serta jam kerja yang dicurahkan dalam kegiatan pemupukan . Dari 17 responden dalam penelitian ini yang melakukan kegiatan pemupukan 11 responden dan 6 responden tidak melakukan kegiatan pemupukan karena kegiatan pemupukan dilakukan oleh laki-laki, Tabel 8 menunjukkan jumlah dan persentase pada kegiatan pemupukan.

Hasil penelitian menunjukan bahwa pada kegiatan pemupukan jam per minggu jumlah jam yang dicurahkan sebasar 3,08 jam dengan persentase $5,50 \%$ dan rata-rata 0,18 jam per responden pada kegiatan pemupukan wortel.

\section{Kegiatan Pengendalian Hama dan Penyakit}

Dalam kegiatan pengendalian hama dan penyakit dalam usahatani wortel dilakukan dengan cara penyemprotan pestisida. Dalam penelitian ini ingin dilihat bagaimana peran tenaga kerja wanita dalam kegiatan pengendalian hama dan penyakit jam per minggu serta jam kerja yang dicurahkan dalam kegiatan pengendalian hama dan penyakit. Tabel 8 menunjukkan jumlah dan persentase pada kegiatan pengendalian hama dan penyakit.

Hasil penelitian menunjukkan bahwa pada kegiatan pengendalian hama dan penyakit jam per minggu tidak ada wanita yang berperan atau memberikan curahan waktu kerjanya pada kegiatan pengendalian hama dan penyakit, karena pada kegiatan pengendalian hama dan penyakit di kelurahan Rurukan hanya dilakukan oleh laki-laki.

\section{Kegiatan Panen}

Kegiatan pemanenan dilakukkan setelah 3 bulan dari waktu penanaman benih, Dalam penelitian ini ingin dilihat bagaimana tenaga kerja wanita dalam kegiatan pemanenan dengan melihat jumlah curahan waktu kerja dalam kegiatan panen. Tabel 8 menunjukkan jumlah jam dan persentase waktu kerja wanita dalam kegiatan panen.
Hasil penelitian menunjukkan bahwa pada kegiatan panen jam, tidak ada wanita yang memberikkan curahan waktu kerjanya pada kegiatan ini karena dalam kegiatan panen pembeli yang datang ke kebun untuk memanen tanaman wortel.

\section{KESIMPULAN DAN SARAN}

\section{Kesimpulan}

Hasil penelitian menunjukkan bahwa curahan waktu kerja wanita dalam keluarga petani wortel di Kelurahan Rurukan Jam per minggu lebih tinggi/banyak pada jenis pekerjaan didalam keluarga yaitu sebesar 251 jam per minggu dan rata-rata 14,76 jam per responden, dan curahan waktu kerja di luar keluarga (usahatai wortel) jam per minggu sebesar 56,16 jam dan rata-rata 3,30 jam per responden.

\section{Saran}

Diharapkan pada kegiatan usahatani wortel wanita ikut mencurahkan waktu kerja dalam kegiatan pengendalian hama dan penyakit tidak hanya laki-laki.

\section{DAFTAR PUSTAKA}

Novita, R. 2012.Faktor-Faktor Yang Mempengaruhi Curahan Waktu Kerja Wanita Tani Pada Usahatani Padi Sawah(Studi Kasus Di Desa Ngarjo Kecamatan Mojoanyar Kabupaten Mojokerto). Universitas Briwijaya. Malang. Sofwan, 2016. Analisis kontribusi dan Curahan Tenaga Kerja Wanita Tani pada Usahatani Tembakau Terhadap Pendapatan Keluarga. Jurnal Trisul LP2M Undar edisi 4 Vol.1

Widyarini, I., Putri, D. D., \& Karim, A. R. (2013). Peran Wanita Tani Dalam Pengembangan Usahatani Sayuran Organik Dan Peningkatan Pendapatan Keluarga Di Desa Melung Kecamatan Kedungbanteng. Pembangunan Pedesaan, 13(2).

Zannatos, Zafiris. 2004. Pertumbuhan Adjusment Dan Pasar Tenaga Kerja, Efek Pada Wanita Pekerja Keras DiSampaikan Pada Konfrehensi Internasional Ke-4 Assoviation Untuk Femisi, Ekonomi Efrancoise, Tabelis, Tours Prancis, 5-7 juli. 